\title{
Removal of hard COD, nitrogenous compounds and phenols from a high-strength coal gasification wastewater stream
}

\author{
E Rava ${ }^{1 *}$, E Chirwa', P Allison ${ }^{2}$, M van Niekerk ${ }^{3}$ and MP Augustyn ${ }^{3}$ \\ 'University of Pretoria, Water Utilisation Division, 0002, South Africa \\ ${ }^{2}$ Scientific and Technical Consulting Services, P.O. Box 699, Port Alfred 6170, South Africa \\ ${ }^{3}$ Sasol Technology (Pty) Ltd, Private Bag X1034, B4901, Secunda 2302, South Africa
}

\begin{abstract}
The objective of this study was to identify the factors affecting the suspended and fixed biomass in the removal of hard COD, nitrogenous compounds and phenols from a coal gasification wastewater (CGWW) stream using a hybrid fixedfilm bioreactor (H-FFBR) process under real-time plant operational conditions and actual wastewater composition. The composition of the influent and effluent was studied to determine which compounds were not removed by hydrolysis (bacterial activity) and how this correlated to the suspended and fixed biomass activity, COD and phenol removal. A H-FFBR with $12 \mathrm{~g} \cdot \mathrm{m}^{-3}$ attached biomass and $440 \mathrm{mg} \cdot \ell^{-1}$ suspended biomass achieved $78 \%$ phenol removal and $49 \%$ COD removal but insignificant removal of nitrogenous compounds. During the operation period, fixed biomass concentration was higher than the suspended biomass. Parameters such as $\mathrm{pH}$, phenols, alkalinity, metal ions, conductivity, total dissolved solids and aeration rate affected the fixed biofilm properties such as adhesion, thickness and structure. It can be concluded that the composition of the effluent had a direct effect on the fixed biomass properties and thus a direct effect on the removal of phenols, COD and nitrogenous compounds in the wastewater.
\end{abstract}

Keywords: ammonia stripping, AnoxKaldness, coal gasification, fixed-biofilm reactor, hydantoins, phenosolvan, Pseudomonas, refinery effluent, thiocyanate

\section{INTRODUCTION}

Coal gasification wastewater (CGWW) is generated in coal gas purification which poses numerous environmental problems in many countries. The chemical composition of coal gasification wastewater is complex and varies from one plant to another. The generated wastewater can contain ammonia, cyanide, thiocyanate, monohydric phenols, dihydric phenols, polycyclic hydroxyl compounds, monocyclic n-aromatics, polycyclic aromatics and aliphatic acids. Of these compounds the phenolic components, primarily, methyl-phenol, and phenols, constitute between 60 and $80 \%$ of the organic content (Li et al., 2003).

Physico-chemical methods for the extraction of the phenolic content have been realised in order to reduce the toxicity of the waste stream before conventional treatment. Such treatments as the Phenosolvan process for phenol recovery have been investigated. The Phenosolvan process employs a liquid-liquid extraction process where the incoming gas liquor is filtered through a gravel bed and then contacted with the solvent di-isopropyl ether (DIPE) (Beychok, 1974) or butyl ethanoate (Anastasi, 1980) in multistage mixer-settlers (Beychok, 1974; Bryant et al., 1988). The phenol-rich solvent (extract) is distilled to recover lean solvent for reuse and then stripped to remove and recover residual solvent (Beychok, 1974). The dephenolised liquor (raffinate) is gas-stripped to remove and recover solvent (Beychok 1974; Bryant et al., 1988). The liquor is then steam-stripped to remove acid gases (hydrogen sulphide and carbon dioxide), followed by steam-stripping to remove ammonia (Beychok, 1974).

As can be seen from above, the physico-chemical extraction method is complex, is difficult to optimise, and leaves

\footnotetext{
* To whom all correspondence should be addressed. ¿ +27(0)833978524, e-mail: emrava@buckman.com Received 7 April 2014; accepted in revised form 28 May 2015
}

room for error. Due to the apparent difficulty and cost of utilising such a complex process, it has become necessary to investigate cheaper and more robust methods for treatment of the CGWW. One such possibility is the use of hybrid and homogeneous fixed-film reactor systems to take advantage of the mixed culture communities capable of metabolising a range of recalcitrant organics in biofilm environments (Stoodley et al., 1999).

Biological treatment has been widely used only to treat the wastewater following pre-treatment by processes of ammonia stripping and phenol solvent extractions to reduce the concentration of toxic compounds (Li et al., 2011). As part of the conventional treatment process, biofilm processes are widely utilised to eliminate the organic carbon and nitrogen content of the wastewater. In biofilm processes, bacteria are grown on suspended carrier particles, fluidised on flocs, or fixed on immobile structures within the reactor. Such processes are aimed to extend the cell retention time (sludge age) of the system indefinitely (Li et al., 2003).

In the biofilm system, the cells are held together by microbial secretions of various polysaccharides that act as a gel-like matrix surrounding the cells (Nelson et al., 1996). This encapsulated structure results in the formation of concentration gradients for all relevant dissolved compounds due to microbial activity and diffusion. The biofilm-associated micro-organisms detach from the surface of the biofilm to populate a planktonic phase that contributes to the removal of organic carbon and nitrogen. The attached biofilm and suspended biomass make the fixed-film bioreactor (FFBR) a hybrid reactor (H-FFBR) rather than an exclusively attached or suspended phase system (Goode, 2010).

\section{MATERIALS AND METHODS}

Composite samples $(1000 \mathrm{ml})$ of the influent stream and effluent stream (clarifier overflow) were collected at a rate of $50 \mathrm{~m} \ell \cdot \mathrm{h}^{-1}$, and $\mathrm{pH}$, suspended solids (SS), chemical oxygen demand (COD), 
ammonium-nitrogen $\left(\mathrm{NH}_{4}-\mathrm{N}\right)$, nitrate-nitrogen $\left(\mathrm{NO}_{3}-\mathrm{N}\right)$, ortho-phosphate $\left(\mathrm{o}-\mathrm{PO}_{4}\right)$, total dissolved solids, conductivity and total phenols were measured using Standard Methods (APHA, 2012). Each aeration zone was linked to a data-collection-system (DCS) and parameters such as temperature, dissolved oxygen (DO), recycling rate, feed rate, de-sludging rate, hydraulic retention time, $\mathrm{pH}$ and hydraulic sludge age were controlled and optimised automatically. The oxygen uptake rate (OUR) of the fixed biomass solids was measured on-site using a HACH model HQ40d multimeter with a LDO 101 probe (Hou et al., 2014). A BOD sample bottle $(300 \mathrm{~m} \ell)$ was filled with $150 \mathrm{~m} \ell$ effluent and topped up with $150 \mathrm{~m} \ell$ AnoxKaldnes K1 carrier media taken from the respective zones, to simulate a $50 \%$ media fill fraction (by volume). The suspended biomass OUR was measured by the same procedure; however, no carrier medium was added (Blanc et al., 2010). The dissolved oxygen (DO) was measured every minute for a period of $10 \mathrm{~min}$. The OUR rates at $36^{\circ} \mathrm{C} \pm 1$ were calculated by linear regression obtained from the plot of DO concentration versus time (Qiqi et al., 2012). Fixed biomass solids on the carrier were measured by first rinsing with tap water $(3 \mathrm{x})$, then drying duplicate samples, consisting of 100 carriers each, at $105^{\circ} \mathrm{C}$ for $24 \mathrm{~h}$. The dried carriers were weighed and the solids removed by mixing carriers with $150 \mathrm{m \ell} 0.25 \mathrm{~N} \mathrm{NaOH}$ for $24 \mathrm{~h}$. The alkali wash was repeated followed by sonication for $90 \mathrm{~min}$. The carriers were then rinsed well with tap water and dried for $24 \mathrm{~h}$ at $105^{\circ} \mathrm{C}$ and re-weighed. The difference in mass was used to determine the biomass on the carriers (Goode, 2010). Scanning electron microscopy (SEM) and energy dispersive X-ray analysis (EDX), conducted by the University of KwaZulu-Natal (Westville, South Africa), were used to determine the structure, thickness and composition of the fixed biomass. Gas chromatography-mass spectrometry (GC-MS) organic fingerprinting was performed by ERWAT (Kempton Park, South Africa).

\section{Pilot plant design and operating parameters}

The H-FFBR $(1000 \ell)$ consisted of 3 aeration compartments (Zone 1, Zone 2, Zone 3) (Van Leeuwen, 1989) containing acclimatised fixed and suspended biomass (DiMassimo and Bundgaard, 2011; Boltz et al., 2009). The CGWW was diluted to $33 \%$ to reduce the toxicity towards the biomass and to maintain an influent COD concentration around $2000 \mathrm{mg} \cdot \ell^{-1}$ (Li et al., 2011; Zhou et al., 2014). Dilution was 1 part CGWW to 2 parts recycled sludge (Luthy et al., 1980). The reactor was operated at $36^{\circ} \mathrm{C} \pm 1$ (Merlo et al., 2011) and monitored for a 6-month period. The $\mathrm{pH}$ was adjusted with $20 \%(\mathrm{~m} / \mathrm{v})$ sulphuric acid $\left(\mathrm{H}_{2} \mathrm{SO}_{4}\right)$ or $10 \%(\mathrm{~m} / \mathrm{v})$ sodium hydroxide $(\mathrm{NaOH})$ to maintain a pH range between $\mathrm{pH} 6.5$ and $\mathrm{pH}$ 7.5. Plastic biofilm carrier filling fraction (based on volume) for each aeration zone was approximately $70 \%, 50 \%$ and $30 \%$, respectively. A filling ratio of $\leq 70 \%$ allowed the plastic media to move freely, minimising dead or unused space in the reactor (Ratcliffe et al., 2006; Zafarzadeh et. al., 2011). A 70\% filling (Zone 1) of biofilm carrier media (AnoxKaldnes K1) corresponded to an effective biofilm growth area equal to $350 \mathrm{~m}^{2} \cdot \mathrm{m}^{-3}$; therefore, a $50 \%$ fill would equal 250 $\mathrm{m}^{2} \cdot \mathrm{m}^{-3}$ and a $30 \%$ fill would equal $150 \mathrm{~m}^{2} \cdot \mathrm{m}^{-3}$ for Zone 2 and Zone 3, respectively (Ratcliffe et al., 2006; Ayun et al., 2008). Jing et al. (2009) reported that a carrier fill of between $30 \%$ and $50 \%$ was suitable to treat a coking plant wastewater. Qiqi et al. (2012) reported minimal difference in performance between a $33 \%$ and $66 \%$ carrier filling; however, at a filling of $70 \%$ the attached growth density was 5 to 13 times higher and responded more strongly to influent COD than that of activated sludge floc found in suspended activated sludge systems.
A defoamer suitable for biological processes was used during excessive foaming periods in the respective aeration zones. In general, Zone 3 tended to foam the most over the 6-month test period. Bryant et al. (1985) reported that foaming tended to be high in aeration zones having the highest COD removal rates; when steady operating states were not being achieved; when biodegradable compounds were not degraded biologically during an upset; and/or when total dissolved solids (TDS) were high in the influent stream.

\section{RESULTS AND DISCUSSION}

Composite samples of the CGWW feed and effluent streams were collected and the main organic compounds in each stream were identified using GC-MS. The compounds identified in the CGWW were phenols, straight-chain carboxylic acids, aromatic carboxylic acids, ketones, diesel range organics (DRO), hydroquinones, indoles and hydantoins. The effluent stream consisted mainly of hydantoins, traces of carboxylic acids, traces of diesel range organics and phenols, thus indicating that the biological process was effective in removing carboxylic acids, monohydric phenols and hydroquinones, but not, however, polyhydric phenols, diesel range organics and hydantoins (5,5-dimethyl-hydantoin and 5-methyl-5-ethyl-hydantoin). The composition of the CGWW differs with different coal supplies, gasification processes and conditions. Beychok (1974) reported the presence of $75 \%$ to $85 \%$ monohydric phenols (phenols, cresols), $30 \%$ to $35 \%$ dihydric phenols (catechol, resorcinol and hydroquinones), organic acids (naphthenic acid), neutral oils and organic bases (pyridine) in gas liquor. Li et al. (2003) reported 27.6\% methyl-phenol, $11.4 \%$ quinolinones, $10 \%$ dimethyl-phenol, $10 \%$ indole, $9.5 \%$ phenol, $6.7 \%$ methyl-quinolinone, and 5\% isoquinolinone. Lignite coals (low-ranking coal) are a source of high amounts of aromatic compounds with higher oxygen content than higher-ranking coals (Kapusta and Stanczyk, 2011). Low-rank coal contains large amounts of polar groups such as $-\mathrm{OH},-\mathrm{COO},-\mathrm{O},-\mathrm{N}$, and $-\mathrm{S}$, and exhibit mostly hydrophilic behaviour (Molva, 2004).

Hydantoins are non-volatile, highly polar heterocyclic compounds, documented as being poorly biodegradable or nonbiodegradable and which are not removed by solvent extraction with DIPE or steam stripping (Turner et al., 1985). Pavilovich and Luthy (1988) reported that 5,5-dimethyl- hydantoin (DMH) was slightly more soluble in aqueous media than 5-methyl-5-ethyl-hydantoin and both could form complexes with transition metals at $\mathrm{pH} 8.5$.

Hyantoins are specific to slagging fixed-bed gasification and typical concentrations of $630 \mathrm{mg} \cdot \ell^{-1}$ have been reported by Strain and Turner (1985), and of $1700 \mathrm{mg} \cdot \ell^{-1}$ to $2600 \mathrm{mg} \cdot \ell^{-1}$ by Pavlovich and Luthy (1980), after pre-treatment of the liquor by solvent and gas stripping. Cyanide combines with carbon dioxide, ammonia and a ketone during the gas-quenching process to form hydantoins at $\mathrm{pH} 8.5$ (Diehl et al., 1985). If the ketone is 2-butanone (MEK) then 5-methyl-5-ethyl- hydantoin (EMH) is formed; if it is 4-methyl-2-pentanone (MIBK) then 5,5-dimethyl- hydantoin (DMH) is formed (Turner et al., 1985). Ketones and hydantoins are present in low-rank (lignite) coal (Olson et al., 1985).

\section{Removal of phenols}

The removal of total phenols in the H-FFBR ranged between $62 \%$ and $93 \%$ with an average of $78 \%$; thus $22 \%$ of the total phenols were soluble, but recalcitrant (Fig. 1). The removal of 
phenols is affected by factors such as biodegradation kinetics, substrate inhibition effect, $\mathrm{pH}$, temperature, biomass concentration, microbial community and their metabolic potential, and nutrient concentration (Lepik and Tenno, 2011). Biodegradation depends on the structures of the phenolic compounds and the number of substituents on the aromatic nucleus. Biodegradation is also affected by the positions of the methyl groups of methylphenols. The $p$-substituted phenols are more readily biodegradable than the $m$ - or the $o$-substituted phenols since they are weaker electron donors (Adabju, 2013).

Marrot et al. (2006) reported the optimum $\mathrm{pH}$ for phenol degradation to be between 6.5 and 7.5, Crutescu et al. (2008) reported a degradation rate of between $95 \%$ and $99 \%$ at $\mathrm{pH}$ between 6.8 and 7.5, Chakraborty et al. (2010) reported the highest phenol degradation rate $(83 \%)$ at $\mathrm{pH} 7.0\left(30^{\circ} \mathrm{C}\right)$; however, the rate of degradation at $35^{\circ} \mathrm{C}$ would still be considerable but less than that at $30^{\circ} \mathrm{C}(<83 \%)$. Arutchelvan et al. (2006) reported that temperature $\left(34^{\circ} \mathrm{C}\right)$ and $\mathrm{pH}$ (8.0) influenced the rate of phenol degradation to a maximum of 1 $750 \mathrm{mg} \cdot \ell^{-1}$. Lim et al. (2013) reported a pH between 7.3 and 7.8 for phenol degradation. A healthy biomass (acclimatised to wastewater constituents) requires a pH between 6.5 and 8.5 (Merlo et al., 2011).

In this study, phenol removal efficiencies of $62-93 \%$ were measured in the operation of the H-FFBR treating CGWW with the incoming $\mathrm{pH}$ controlled to $\mathrm{pH}$ 6.5-7.9 using acid or alkali, and a temperature of $36^{\circ} \mathrm{C} \pm 1$. These results are higher than a phenol reduction of $83 \%$ at $\mathrm{pH} 7$ and $30^{\circ} \mathrm{C}$ as published by Chakraborty et al. (2010) and lower than $95-99 \%$ as reported by Crutescu (2008) for a $\mathrm{pH}$ range of 6.8-7.5.

\section{Removal of soluble COD}

The removal of soluble COD ranged between $37 \%$ and $62 \%$ with an average of $49 \%$ (Fig. 2). Turner et al. (1985) reported that the presence of 5,5-dimethyl-hydantoin and related compounds in the condensate waters accounted for $1 \%$ to $6 \%$ of the COD, phenols $59 \%$ to $76 \%$ of the COD, and dihydroxy benzenes $0.02 \%$ to $9.5 \%$ of the COD. Galil et al. (1988) reported COD removal of $40 \%$ to $60 \%$ when biologically treating similar coal condensate (solvent-extracted and ammonia-stripped), which is in line with the COD removal efficiencies obtained in this study.

The H-FFBR was not effective in removing all the hydantoins, aromatic carboxylic acids and diesel range organics (DRO). These results correlate with reports that biological oxidation provided good removal of many organic compounds, but that aromatic hydrocarbons containing aliphatic substitutions and certain polycyclic aromatic hydrocarbons $(\mathrm{PAH})$ were only partially removed.

Wang et al. (1999) reported that phenolic compounds were the main organic components of coal gasification wastewater and made up more than $60 \%$ of the total organic carbon. Merlo et al. (2011) reported that $13 \%$ of COD in petroleum refinery effluent was non-biodegradable. Moretti and Neufeld (1989) reported that most of the COD was due to the presence of $\mathrm{DMH}$ and $\mathrm{EMH}$, of which $1 \%$ to $6 \%$ was due to $\mathrm{EMH}, 59 \%$ to $76 \%$ due to $\mathrm{DMH}$, and $38 \%$ to $85 \%$ due to phenols.

Mirhossaini et al. (2010) reported that the amount of COD in the influent stream resulted in competition between heterotrophs and autotrophs and therefore defined the total biomass and biofilm composition as well as oxygen diffusion into the biofilm. The total biomass population was thus heterotrophic since the COD removal rate (Fig. 2) was higher than ammonium-nitrogen removal (Mazumder, 2010). Dürr et al. (2006) reported that heterotrophs belonging to the genera
Arthrobacter, Pseudomonas, Bacillus and Flavobacteruim were able to catalyse the hydrolysis of hydantoins in a ring-opening step by enzymes classified as hydantoinases.

\section{Fixed biomass versus suspended biomass activity}

The average fixed biomass activity was $62.58\left(\mathrm{mg} \mathrm{O}_{2} \cdot \ell^{-1} \cdot \mathrm{h}^{-1}\right)$, $33.80\left(\mathrm{mg} \mathrm{O}_{2} \cdot \ell^{-1} \cdot \mathrm{h}^{-1}\right)$ and $33.71\left(\mathrm{mg} \mathrm{O}_{2} \cdot \ell^{-1} \cdot \mathrm{h}^{-1}\right)$ for the respective aeration zones. The suspended biomass activity was 48.47 $\left(\mathrm{mg} \mathrm{O}_{2} \cdot \ell^{-1} \cdot \mathrm{h}^{-1}\right), 37.48\left(\mathrm{mg} \mathrm{O}_{2} \cdot \ell^{-1} \cdot \mathrm{h}^{-1}\right)$ and $41.31\left(\mathrm{mg} \mathrm{O}_{2} \cdot \ell^{-1} \cdot \mathrm{h}^{-1}\right)$ for the respective aeration zones. The suspended biomass activity was higher than the fixed biomass activity in Zone 2 and Zone 3 (Fig. 3). The biofilm thickness for Zone 1 ranged between $1.79 \mu \mathrm{m}$ and $213 \mu \mathrm{m}$ with an average of $51.45 \mu \mathrm{m}$. The biofilm

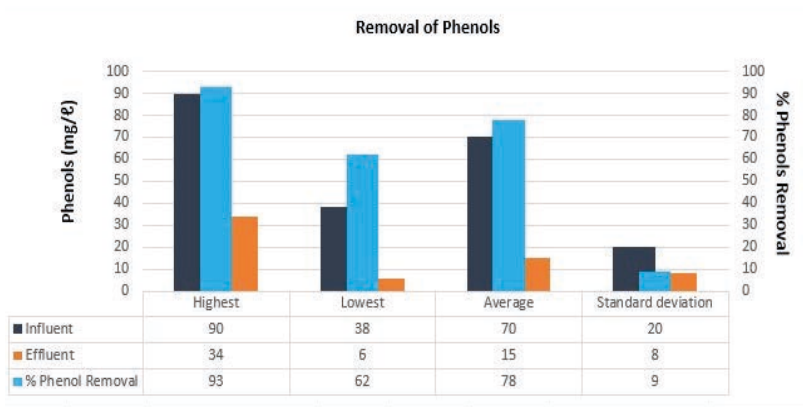

Figure 1

Data distribution of 132 samples tested for $\%$ phenol removal in the operation of the hybrid fixed-film bioreactor (H-FFBR)

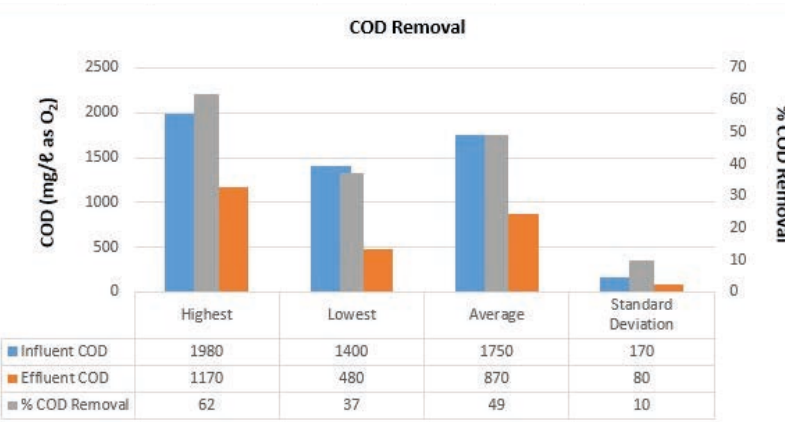

Figure 2

Data distribution of 132 samples tested for $\%$ COD removal in the operation of the hybrid fixed-film bioreactor (H-FFBR)

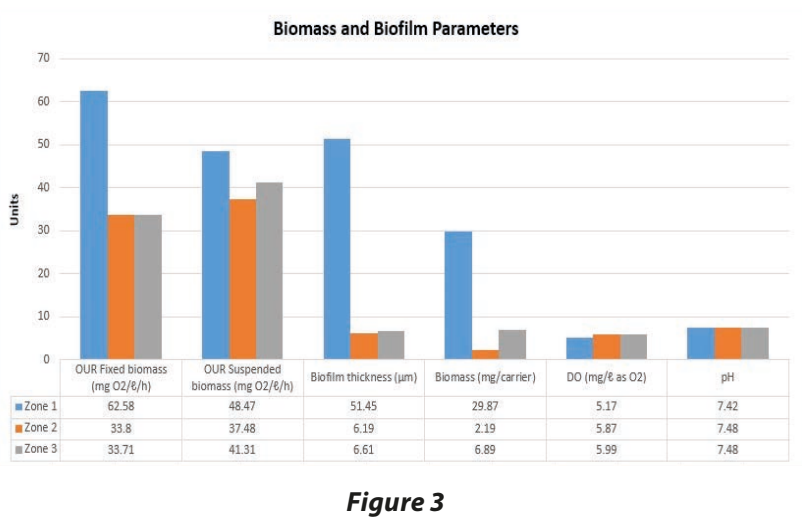

Differences between biomass and biofilm parameters in the respective aeration zones in the operation of the hybrid fixed-film bioreactor (H-FFBR) 
thickness for Zone 2 ranged between $0.47 \mu \mathrm{m}$ and $13.61 \mu \mathrm{m}$ with an average of $6.19 \mu \mathrm{m}$. The biofilm thickness for Zone 3 ranged between $1.45 \mu \mathrm{m}$ and $24.0 \mu \mathrm{m}$ with an average of 6.61 $\mu \mathrm{m}$. There was no direct correlation between fixed biomass thickness and biomass activity. However, there was a correlation between aeration rate and biofilm thickness (Fig. 3). Biofilm thickness is normally between $5 \mu \mathrm{m}$ and $40 \mu \mathrm{m}$ and rarely more than $100 \mu \mathrm{m}$ to $200 \mu \mathrm{m}$ (Ward and King, 2012). Boltz et al. (2009) reported biofilm thickness in aerobic H-FFBR reactors to be in the range of $50 \mu \mathrm{m}$ to $200 \mu \mathrm{m}$. Asiedu (2001) reported the biofilm thickness should be less than $100 \mu \mathrm{m}$ to allow for sufficient substrate diffusion into the biofilm.

Higher aeration rates increased the mixing energy (roll pattern) of the plastic media, resulting in higher shear forces across the biofilm layer (Sen and Randall, 2008), which influenced the biofilm thickness, microbial population and rate of growth. The mixing energy provided by the aeration is critical for sloughing of biomass and the formation of a thin biofilm yielding higher kinetic rates than previously measured in thick biofilm (Hubbell et al., 2006). Higher aeration rates increase the biological activity of the fixed biomass; however, extreme turbulence detaches biofilm from the carrier (Asiedu, 2003). Thin biofilms increase available surface area and reduce variability of solids discharge due to sloughing (Goode, 2010). Sen and Randall (2008) reported that the rate of sloughing and the biofilm yield for heterotrophs and nitrifiers in each cell are dependent on (i) shear forces imparted by mixing and roll pattern, (ii) design of biofilm carrier particle (media), and (iii) substrate and electron acceptor level in each cell. The biofilm thickness is a function of the substrate concentration in the bulk liquid, average mixed liquor volatile suspended solids (MLVSS) of the biofilm and shear forces (Sen and Randall, 2008).

\section{Biofilm structure and properties}

EDX analyses of the fixed biofilm layers indicated the presence of carbon, oxygen, sodium, aluminium, silicon, phosphorus, sulphur, chloride, potassium, calcium, nitrogen, copper and iron for all three aeration zones (Fig 4, 5 and 6). Aluminium, silicon, calcium and iron were found to be highest in Zone 1; nitrogen, oxygen, sodium, magnesium, sulphur, chloride and potassium highest in Zone 2, and carbon, phosphorus and copper highest in Zone 3 (Table 3). The same inorganic elements were reported by Revanuru and Mishra (2011), who reported that the silicon and aluminium increased biofilm resistance to toxic shocks and the presence of iron and sulphur contributed to the aggregation of biomass. Potassium, magnesium, sodium, calcium, iron and chlorides are macronutrients required for membrane stabilisation. Micronutrients such as zinc, manganese, molybdenum, selenium, copper, cobalt, nickel, vanadium and tungsten have been reported to allow proper function of enzymes. Hu et al. (2013) reported that calcium and phosphorus absorb and accumulate in the biofilm as insoluble compounds rendering the biofilm highly resistant to detachment. Todar (2006) reported that sulphur was required for protein synthesis, phosphorus for nucleic acids and metabolic cofactors, and nitrogen for proteins, some sugars and nucleic acids.

Goode (2010) reported that the extracellular polymeric substance (EPS) acts as an ion exchange resin where divalent bridges can be formed or broken due to relative concentrations of monovalent and divalent cations competing for negative sites. The presence of divalent cations $\left(\mathrm{Ca}^{2+}, \mathrm{Mg}^{2+}, \mathrm{Fe}^{2+}\right)$ influences biofilm formation directly through its effect on electrostatic interactions, and indirectly via physiologically-dependent attachment processes by acting as cellular cations and enzyme cofactors. Calcium ions also impact the mechanical properties of the biofilm by acting as cross-linkers and making the extracellular polymeric substances more proteinaceous (Song and Leff, 2006).

In general, biofilms become thicker (lower detachment rate), denser and more mechanically stable (mature biofilm) when exposed to increasing concentrations of divalent cations.

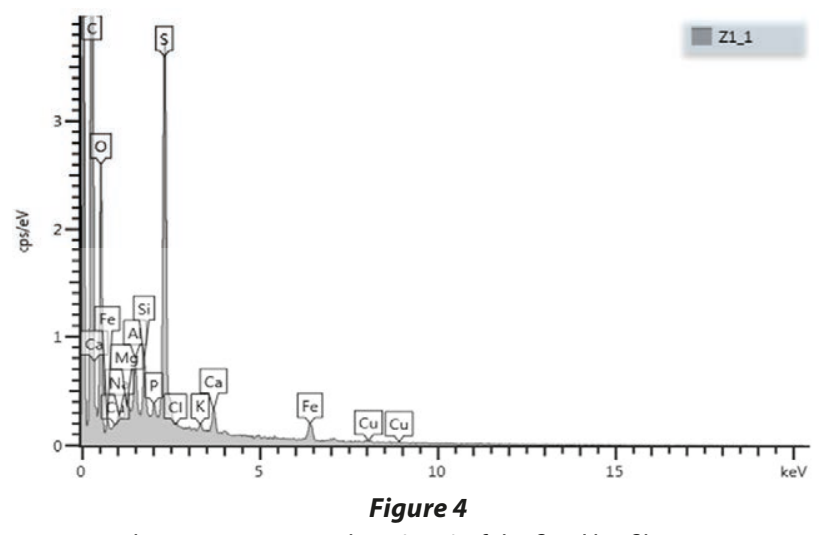

Energy dispersive $X$-ray analysis (EDX) of the fixed biofilm in aeration Zone 1 (Z1_1) in the operation of the hybrid fixed-film bioreactor (H-FFBR)



Energy dispersive $X$-ray analysis (EDX) of the fixed biofilm in aeration Zone 2 (Z2_1) in the operation of the hybrid fixed-film bioreactor (H-FFBR)



Energy dispersive $X$-ray analysis (EDX) of fixed biofilm in aeration Zone 3 (Z3_1) in the operation of the hybrid fixed-film bioreactor (H-FFBR) 


\begin{tabular}{|l|c|c|c|}
\hline \multicolumn{4}{|c|}{ Table 1 } \\
\hline \multicolumn{1}{|c|}{ Energy dispersive X-ray analyses of the fixed biofilm } \\
\hline Element & Zone 1 & Zone 2 & Zone 3 \\
\hline Carbon & 67.74 & 66.22 & 0.38 \\
\hline Nitrogen & $<0.1$ & 0.88 & 25.01 \\
\hline Oxygen & 24.66 & 25.70 & 0.22 \\
\hline Sodium & 0.17 & 0.47 & 0.01 \\
\hline Magnesium & 0.10 & 0.19 & 0.22 \\
\hline Aluminium & 0.42 & 0.24 & 0.22 \\
\hline Silicon & 0.41 & 0.10 & 0.28 \\
\hline Phosphorus & 0.24 & 0.21 & 4.23 \\
\hline Sulphur & 4.79 & 4.86 & 0.16 \\
\hline Chloride & 0.10 & 0.37 & 0.15 \\
\hline Potassium & 0.12 & 0.21 & 0.22 \\
\hline Calcium & 0.36 & 0.22 & 0.40 \\
\hline Iron & 0.85 & 0.55 & 0.20 \\
\hline Copper & 0.13 & 0 & \\
\hline
\end{tabular}

Unit: \% by weight

However, elevated calcium levels could lead to the accumulation of inorganic salts and thus reduce the effective surface area of the biofilm (Goode, 2010). DMH is a weak acid and complexes with metals in the anionic form, thus affecting the equilibrium chemistry and speciation of calcium (Pavlovich and Luthy, 1988).

Scanning electron microscopy (SEM) analyses indicated the fixed biofilm morphology to be relatively uniform and dense for Zone 1 (Fig. 7), 'rippling' for Zone 2 (Fig. 8) and 'porous' for Zone 3 (Fig. 9). Lembre et al. (2012) reported that the bending of biofilm structures in the same direction of the shear force was due to the viscoelasticity response of a mixed culture biofilm. Goode (2010) reported that a porous structure was found to allow greater diffusion of dissolved solids compared to a homogenous biofilm. Ward and King (2012) reported that biofilms are initially homogenous, and then become heterogeneous complex structures when mature.

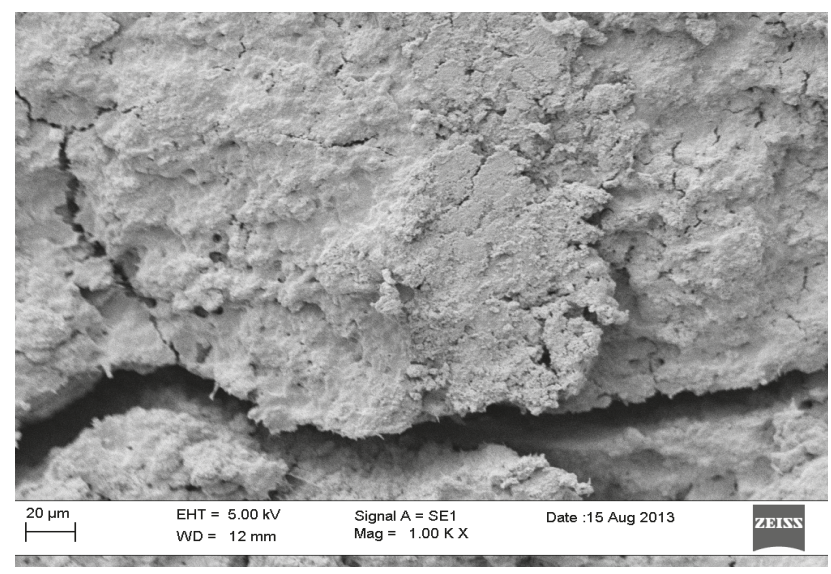

Figure 7

Scanning electron microscopy (SEM) of the fixed biofilm in Aeration Zone 1

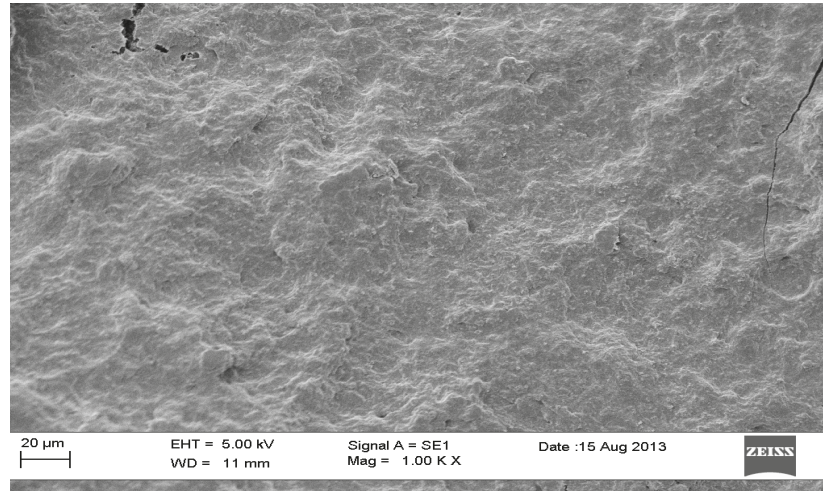

Figure 8

Scanning electron microscopy (SEM) of the fixed biofilm in Aeration Zone 2

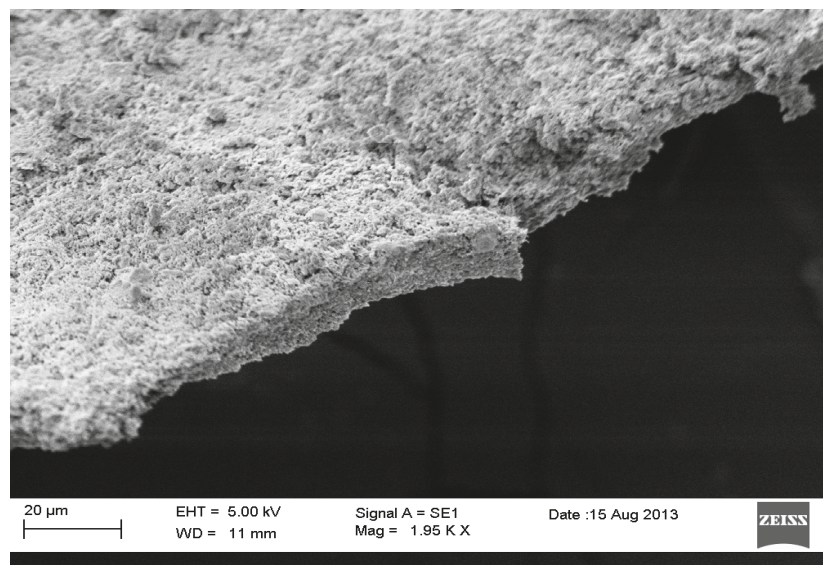

Figure 9

Scanning electron microscopy (SEM) of the fixed biofilm in Aeration Zone 3 
Electrolyte concentration (osmolarity, conductivity) and nutrient concentration also affect biofilm morphology (Song and Leff, 2006). Biofilms are thicker and denser at higher nutrient concentration and the morphology of an established biofilm changes as the carbon concentration changes (Song and Leff, 2006). Increasing biofilm thickness and reducing diffusion of oxygen into the deeper regions of the biofilm would lead to better retention of denitrifiers (Goode, 2010).

Commercially available bio-augmentation products specifically designed for refinery wastewater were tested in the laboratory (results not included). Results indicated a 30\% improvement in the removal of soluble COD. However, this needs to be confirmed on the pilot plant under similar operating conditions.

\section{CONCLUSIONS}

The results show that a hybrid fixed-film bioreactor (H-FFBR) can be successfully used for the removal of chemical oxygen demand (COD) and total phenols from coal gasification wastewater (CGWW). The attached biomass activity was higher than the suspended biomass activity. Thus, the removal of COD and total phenols was performed mainly by the attached biomass. Both populations were heterotrophic since there was no removal of nitrogenous compounds. The H-FFBR can thus be scaled up for the removal of COD and total phenols from CGWW. However, from an environmental perspective, bioaugmentation should be investigated further for enhancing the removal of COD, total phenols and nitrogenous compounds.

\section{ACKNOWLEDGEMENTS}

The authors would like to thank Buckman Africa for funding the chemical, EDX, GC-MS and SEM analyses and Sasol Technology (Pty) Ltd for the use and operation of the pilot plant.

\section{REFERENCES}

ADABJU S (2013) Specific moving bed biofilm reactor for removal of synthetic municipal wastewater. MSc dissertation, University of Technology, Sydney, Australia.

ANASTASI JL (1980) Sasol: South Africa's oil from coal story. EPA report 600/8/80-002. URL:http://www.fischer-tropsch.org/DOE/ DOE_reports/600_8-80-002/epa-600_8-80-002.pdf (Accessed 2 January 2014).

APHA (2012) Standard Methods for the Examination of Water and Wastewater (22 $2^{\text {nd }}$ edn). American Public Health Association, Washington, DC. ISBN-13: 978-087553-0130.

ARUTCHELVAN V, KANAKASABAI V, ELANGOVAN R, NAGARAJAN S and MURALIKRISHNAN V (2006) Kinetics of high strength phenol degradation using Bacillus brevis. J. Hazardous Mater. B129 216-222.

ASIEDU K (2001) Evaluating biological treatment systems. MSc dissertation, Virginia Polytechnic Institute and State University, Virginia, USA.

AYUN A, NAS B and BERKTAY (2008) Influence of high organic loading rates on COD removal and sludge production in moving bed biofilm reactor. Environ. Eng. Sci. 25 (9) 1311-1316.

BEYCHOK MR (1974) Coal gasification and phenosolvan process. In: Proceedings of the American Chemical Society $168^{\text {th }}$ Annual Meeting, September 1974, Atlanta City, New Jersey, USA pp 85-93.

BLANC R, ASSULIN N, RACHAMIM S, YALIN T and ARBEL T (2010) Respirometry as a simple operational tool for monitoring of MBBR and IFAS biofilm systems. WEFTEC 16 337-353

BOLTZ JP, JOHNSON BR, DAIGGER GT and SANDINO J (2009)
Modeling integrated fixed-film activated sludge and moving-bed biofilm reactor systems 1: Mathematical treatment and model development. Water Environ. Res. 81 (6) 555-575.

BRYANT CW, CAWEIN CC and KING PH (1988) Biological treatment of in situ coal gasification wastewater. J. Environ. Eng. 114 (2) 400-414.

CHAKRABORTY S, BHATTACHARYA T, PATEL TN and TIWARI KK (2010) Biodegradation of phenol by native microorganisms isolated from coke processing wastewater. J. Environ. Biol. 32 293-296.

CRUTESCU R, FILIPESCU L and VASILESCU P (2008) Influence of operating parameters on degradation process of phenolic wastewaters. U.P.B Bull. Series B 70 (4) 13-28.

DIEHL J, OLSON E and WORMAN J (1985) Kinetics of hydantoin formation. Fuel 65 1019-1021.

DiMASSIMO RW and BUNDGAARD E (2011) Controlled aeration of integrated fixed-film activated sludge bioreactor systems for treatment of wastewater. United States Patent Number US2011/0284461 A1.

DÜRR R, VIELHAUER O, BURTON SG, COWAN DA and PUANL A (2006) Distribution of hydantoinase activity in bacterial isolates from geographically distinct environmental sources. J. Mol. Catal. B: Enzym. 39 160-165.

GALIL N, REBHUN, M and BRAYER Y (1988) Disturbances and inhibition in biological treatment of wastewater from an integrated refinery. Water Sci. Technol. 20 (10) 21-29.

GOODE C (2010) Understanding biosolids dynamics in a moving bed biofilm reactor. $\mathrm{PhD}$ thesis, University of Toronto, Canada.

HOU B, HAN H, JIA S, ZHUANG H, ZHAO Q and XU P (2014) Effect of alkalinity on nitrite accumulation in treatment of coal chemical industry wastewater using moving bed biofilm reactor. J. Environ. Sci. 26 (5) 1014-1022.

HU XB, WANG Z, DING LL and REN HQ (2013) Characteristics of biofilm attaching to carriers in moving bed biofilm reactor used to treat vitamin C wastewater. Scanning 35 (5) 283-291.

HUBBELL SB, PEHRSON R and FLUORNOY W (2006) Webitat advanced IFAS system addresses common fixed media concerns. WEFTEC 7 3057-3063.

JING JY, FENG J and LI WN (2009) Carrier effects on oxygen mass transfer behaviour in a moving bed biofilm reactor. Asia-Pacific J. Chem. Eng. 4 618-623.

KAPUSTA K and STANCZYK K (2011) Pollution of water underground coal gasification of hard coal and lignite. Fuel 90 1927-1934.

LEMBRE P, LORENTZ C and DI MARTINO P (2012) The complex world of polysaccharides. In Tech, Rijeka, Croatia 371-392. ISBN: 978-953-51-0891-1.

LEPIK R and TENNO T (2011) Biodegradability of phenol, rescorcinol and 5-methylresorcinol as single and mixed substrates by activated sludge. Oil Shale 28 (3) 425-446.

LI YM, GU GW, ZHAO JP, QUI YL and YZ P (2003) Treatment of coke-plant wastewater by biofilm systems for removal of organic compounds and nitrogen. Chemosphere 52 997-1005.

LI H, HAN H, DU M and WANG W (2011) Inhibition and recovery of nitrification in treating real gas coal gasification wastewater with moving bed biofilm reactor. J. Environ. Sci. 23 (4) 568-574.

LIM J, SENG C, LIM P, NG S, TAN S and KEW S (2013) Response of low-strength phenol acclimated activate sludge to shock loading of high phenol concentrations. Water SA 39 (5) 695-700.

LUTHY RG, ASCE AM, SEKEL DJ and TALLON J (1980) Biological treatment of synthetic fuel for wastewater. J. Environ. Eng. Div. 106 (EE3) 609-629.

MARROT B, BARRIOS-MARTINEZ A, MOULIN P and ROCHE N (2006) Biodegradation of high phenol concentration by activated sludge in an immersed membrane bioreactor. Biochem. Eng. J. 30 174-183.

MAZUMDER D (2010) Simultaneous COD and ammonium nitrogen removal from a high-strength wastewater in a shaft-type aerobic hybrid reactor. Int. J. Environ. Sci. Dev. 1 (4) 327-332.

MERLO R, GERHARDT MB, BURLINGHAM F, DE LAS CASAS, C, GILL E and FLIPPIN TH (2011) Petroleum refinery stripped sour water treatment using the activated sludge process. Water Environ. Res. 83 (11) 2067-2078. 
MIRHOSSAINI SH, GODINI H and JAFARI A (2010) Effect of influent COD on biological ammonia removal efficiency. Eng. Technol. 38 315-317.

MOLVA M (2004) Removal of phenol from industrial wastewaters using lignitic coals. MSc dissertation, Izmir Institute of Technology, Turkey.

MORETTI CJ and NEUFELD RD (1989) PAH partitioning mechanisms with activated sludge. Water Res. 23 (1) 93-102.

NELSON YM, LION LW, SHULER ML and GHIORSE WC (1996) Modeling oligotrophic biofilm formation and lead adsorption to biofilm components. Environ. Sci. Technol. 30 (6) 2027-2035.

OLSON ES, WORMAN JJ and DIEHL JW (1985) The formation of hydantoins in gasifier condensate water. ASC Div. Fuel 30 (2) 288-290.

PAVILOVICH GZ and LUTHY G (1988) Complexation of metals with hydantoins. Water Res. 22 (3) 327-336.

QIQI Y, QIANG H and IBRAHIM T (2012) Review on moving bed processes. Pakistan J. Nutr. 11 (9) 706-713.

RATCLIFFE M, ROGERS C, MERDINGER M, PRINCE J, MABUZA T and JOHNSON CH (2006) Treatment of high strength chemical industry wastewater using moving bed biofilm reactor (MBBR) and powdered activated carbon (PAC) technology. WEFTEC 18 1677-1694.

REVANURU S and MISHRA IM (2011) Chemical characteristics of the granular sludge from an UASB reactor treating binary mixture of cathecol and resorcinol in an aqueous solution. IPCBEE 17 128-133.

SEN D and RANDALL CW (2008) Improved computational model (Aquifas) for activated sludge, integrated fixed-film activated sludge, and moving-bed biofilm reactor systems, Part II Multilayer biofilm diffusion model. Water Environ. Res. 80 (7) 624-632.

SONG B and LEFF LG (2006) Influence of magnesium ions on biofilm formation by Pseudomonas fluorescens. Microbiol. Res. 161 355-361.
STOODLEY P, DEBEER D, BOYLE JD and LAPPIN-SCOTT HM (1999) Evolving perspectives of biofilm structure. Biofouling 14 75-94.

STRAIN J and TURNER C (1985) Use of rotating biological contactors for treating coal gasification wastewater. In: Proceedings of the North Dakota Academy of Science - 77 th Annual Meeting, 26-28 April 1985, Dakota, USA.

TODAR K (2006) Todar's Online Textbook of Bacteriology. Department of Bacteriology, University of Wisconsin-Madison, USA.

TURNER C, DIEPOLDER P and STRAIN J (1985) Biological nitrification and hydantoin removal in coal gasification wastewater. In: Proceedings of the $40^{\text {th }}$ Industrial Waste Conference, 14-16 May 1985, Indiana, USA.

VAN LEEUWEN J (1989) Ozonation for non-filamentous bulking control in an activated sludge plant treating fuel synthesis waste water. Water SA 15 (2) 127-132.

WANG S and LOH K (1999) Modeling the role of metabolic intermediates in kinetics of phenol biodegradation. Enzyme Microbiol Technol 25 177-814.

WARD JP and KING JR (2012) Thin-film modelling of biofilm growth and quorum sensing. J. Eng. Math. 73 (1) 71-92.

ZAFARZADEH A, BINA B, NIKAEEN M, ATTAR HM and KHIADANI MH (2011) Effect of dissolved oxygen and chemical oxygen demand to nitrogen ratios on the partial nitrification/ denitrification process in moving bed biofilm reactors. Iranian J. Biotechnol. 9 (3) 197-205.

ZHOU X, LI Y and ZHAO Y (2014) Removal characteristics of organics and nitrogen in a novel four-stage biofilm integrated system for enhanced treatment of coking wastewater under different HRTs. RSC Adv. 4 15620-15629. 